\title{
Mapping and Analysis of the School Network of Makkah Al-Mukarramah (Saudi Arabia), Jeddah Girls' Secondary Schools as Example
}

\author{
Mongi Belarem, Mohamed Hafedh Hamza*, Abdlhamed Jamil, Mohamed Ajmi \\ Department of Geography and Geographic Information Systems, Faculty of Arts and Humanities, King Abdulaziz University, \\ Jeddah, KSA \\ Email: ^mhhamza@kau.edu.sa
}

How to cite this paper: Belarem, M., Hamza, M. H., Jamil, A., \& Ajmi, M. (2018). Mapping and Analysis of the School Network of Makkah Al-Mukarramah (Saudi Arabia), Jeddah Girls' Secondary Schools as Example. Current Urban Studies, 6, 102-120. https://doi.org/10.4236/cus.2018.61005

Received: December 18, 2017

Accepted: March 10, 2018

Published: March 13, 2018

Copyright $\odot 2018$ by authors and Scientific Research Publishing Inc. This work is licensed under the Creative Commons Attribution International License (CC BY 4.0).

http://creativecommons.org/licenses/by/4.0/

\begin{abstract}
The study of the localization of girls' secondary schools in Jeddah shows that the school map is both a diagnostic and perspective tool for school policies. It is also a tool for research, for measuring accessibility and thus for helping decision-makers in the education sector (Ministry of education, regional education directorates, etc.) insofar as it makes it possible to visualize the scenarios of educational facilities. Through the present study, we have developed a map showing the distribution of the girls' secondary schools in Jeddah. This map shows for some households a low accessibility to these schools. That has enabled us to propose facilities to reassure a certain equality of opportunity for access to secondary schools.
\end{abstract}

\section{Keywords}

Mapping, Analysis, Girls' Secondary Schools Network, Jeddah

\section{Introduction}

In recent decades, territorial and demographic changes in the urban area of Jeddah (peri-urbanization, urban extension and extension of the road network, shuttle explosion, etc.) induce changes in the organization of school territories where population growth spaces become under-equipped in schools (Caro et al., 2006a, 2006b). The scholar spatio-institutional dysfunction concerns both the maternal, elementary, primary, secondary and superior of both boys and girls schools.

Exempt from higher education, the agglomeration of Jeddah comprises 2383 educational institutions. They are distributed as follows: 1225 state institutions, 583 private and 575 international. Among these institutions 327 are nursery and 
elementary schools, 964 primary schools, 654 secondary schools and 438 secondary schools. The secondary schools represent $18.38 \%$ of all the educational institutions of the city. Jeddah city includes 194 girls' secondary schools (state, private and international) and 244 boys' secondary schools. This study deals only with public secondary schools for girls (109 secondary schools) which represent $56.18 \%$ of all girls' secondary schools.

In this paper, we begin by presenting the study area as well as the problematic which focuses on the disproportionate urban extension experienced by the city of Jeddah in recent years, and which is marked by an under-equipment of the educational institutions. The introductory part represents also the types and sources of data and used software. Then, in the second part, we present a diagnosis and an analysis of the current state of the spatial distribution of girls' secondary schools which proves that there is a great imbalance between the central and peri-central zones where there is a relatively high density of secondary schools, and the peripheral areas, where girls have to travel long distances to get to high schools. This work is illustrated by a cartographic product showing the structure of the city, the urban extension, the evolution of the land-use and the road network as well as the distribution of the population and that of the secondary schools. Finally, and in the last part, we present some recommendations for improving the accessibility of secondary schools by girls.

The main objective of this study is to visualize and analyze the unequal spatial distribution of girls' secondary schools between the different neighborhoods of the city. It shows that a large mass of the population finds problems of access to high schools. School equipment has not kept pace with urban sprawl and urban population growth.

In this research, we have used the ArcGIS software for the development of the cartographic product based on the results of the processing of the satellite image SPOT 5 of the study area relating to the year 2010 (Hamza et al., 2016) and the 1:25,000 topographic map published in 2012. We also used Excel to realize the graphs presented in the study.

\section{Study Area and Problem Statement}

This study is limited to the urban space of Jeddah which is the second largest in the Saudi urban system. Jeddah city extends on a coastal strip of $4977 \mathrm{~km}^{2}$ on which $930 \mathrm{~km}^{2}$ is totally urbanized. From a small town, even a village, just over half a century ago, Jeddah became now a great metropolis (Al Sulami, 2010). Its area was multiplied by 10 between 1972 and 2010 (Al Sulami, 2010; Daoudi, 2014). The urban mass has grown considerably from 18,315 hectares in 1964 to 54,175 hectares in 2007 (Aljoufie, 2014a) to almost 60,000 hectares in 2014 (Aljoufie et al., 2013b). The city comprises 95 districts (Figure 1) (Hamza et al., 2016). The transport infrastructure has increased rapidly from $101 \mathrm{~km}$ in 1964 to $826 \mathrm{~km}$ in 2007 to almost $1000 \mathrm{~km}$ today (Aljoufie, 2014a). At the end of the 1970 s, the population was estimated at nearly one million inhabitants, rising to 

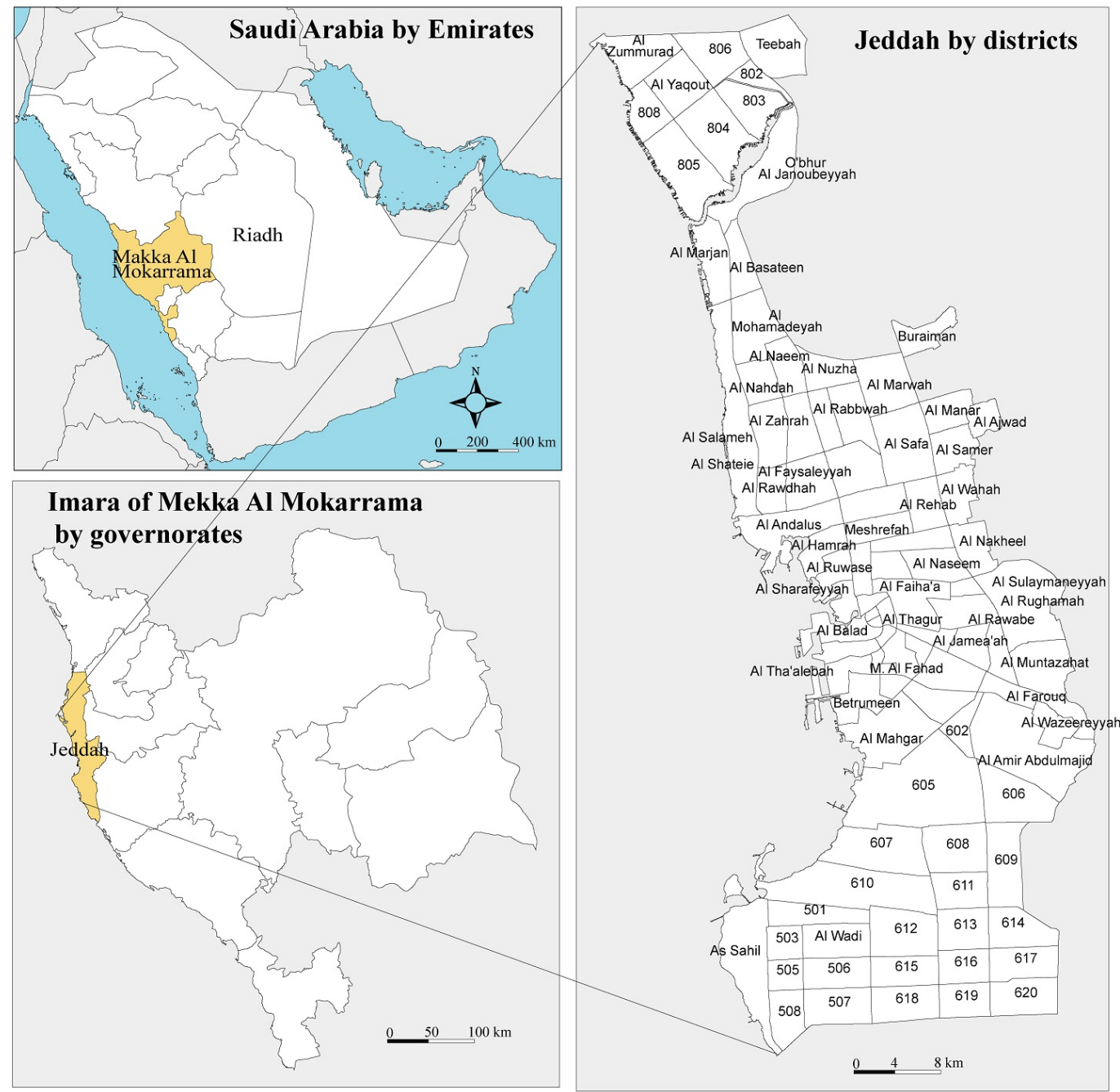

Figure 1. Study area.

1.4 million in 1986, to more than 3 million in 2010, which represents $14 \%$ of the population of Saudi Arabia (EWEA, 2010; Daoudi, 2014). It reached 3.2 million inhabitants in 2012 (Baesse, 2012). Currently, it is estimated at about 3.4 million inhabitants (Hamza et al., 2016), with a 3.5\% growth rate according to Jeddah municipality.

Like the major Saudi cities in recent decades, accelerated urban sprawl (Figure 2, Table 1), disproportionate population growth (Table 1), changes in the road network (Figure 4, Table 1), and dynamics and changes in land use (Al Sulami, 2010; Aljoufi et al., 2013a, 2013b), cause many problems and dysfunctions in Jeddah urban areas (Baesse, 2012). These problems include the fact that equipment in schools has not kept pace with this trend and many areas, especially peripheral ones, are becoming under-equipped in schools. Several sectors of the city have a very remarkable lack of school equipment. In this study, we focus only on pubic girls' secondary schools that exist in the urban area of Jeddah (109 secondary schools). 
M. Belarem et al.

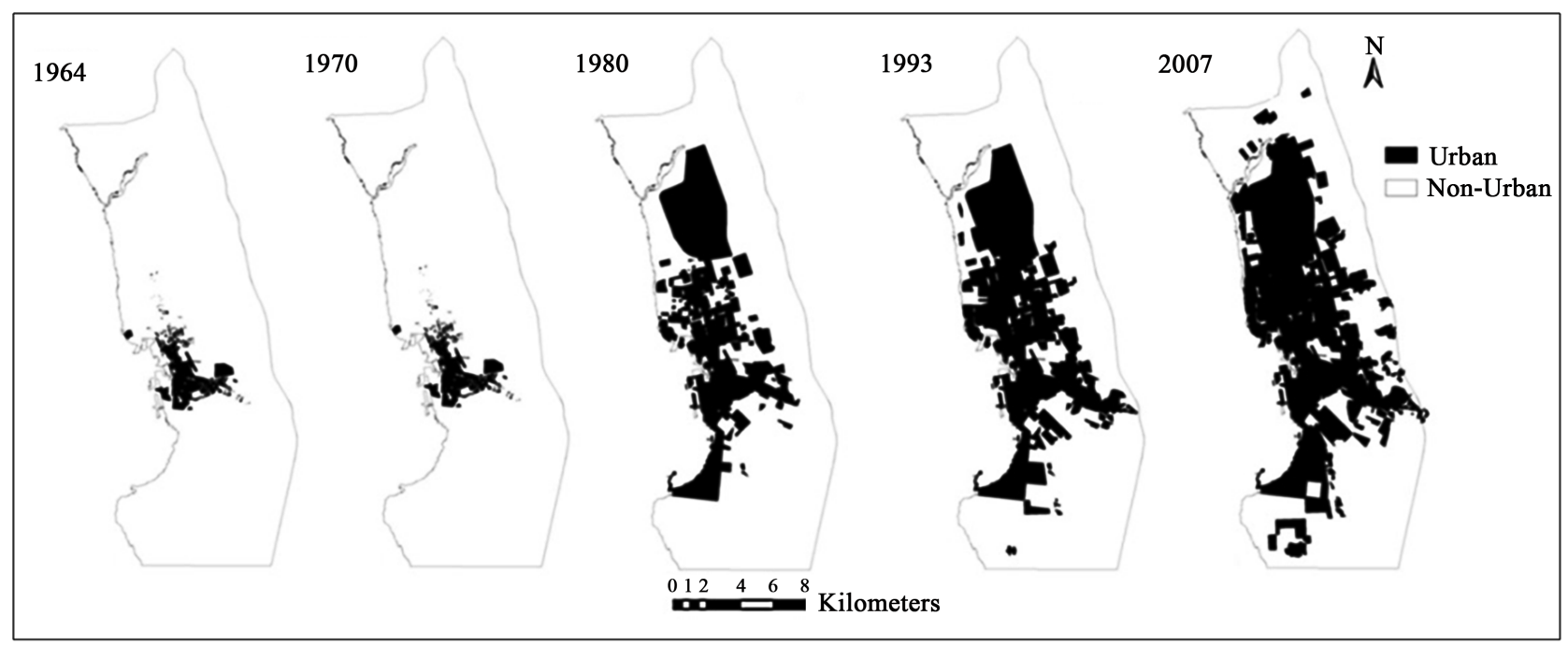

Figure 2. Urban extension of Jeddah city (Aljoufie, 2013b).

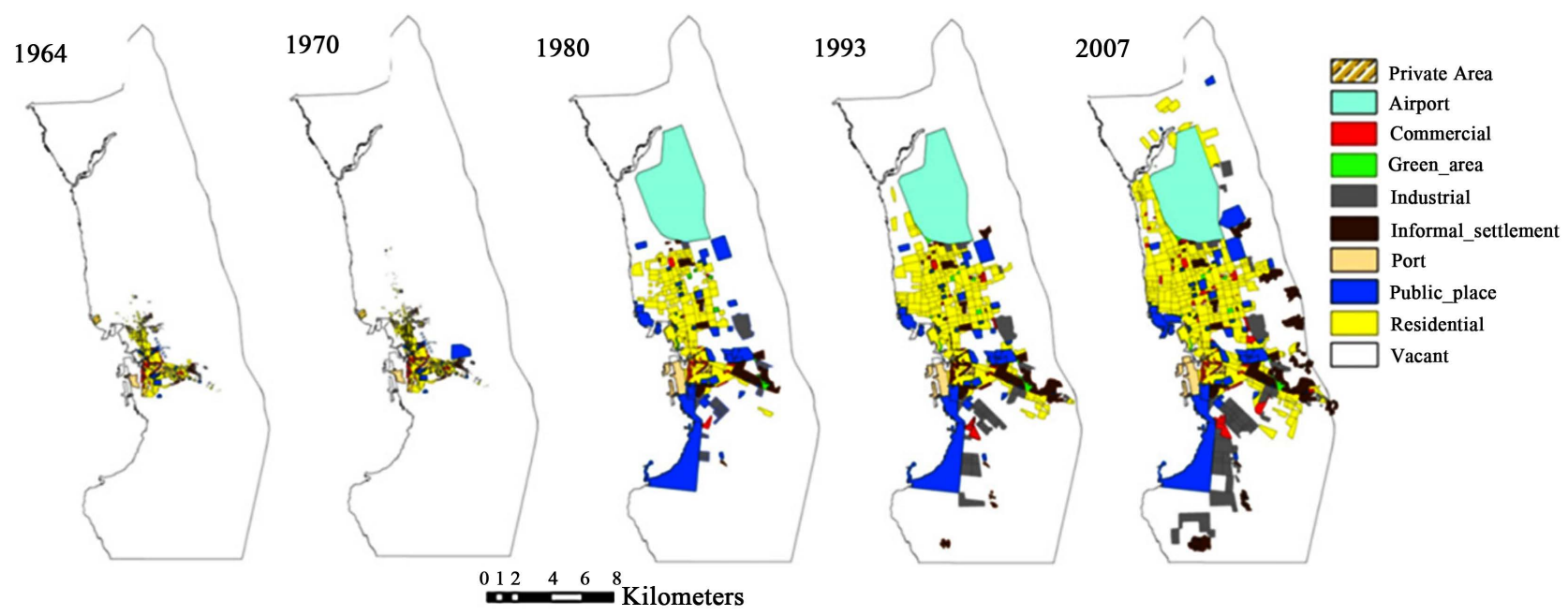

Figure 3. Jeddah city Land use evolution (Aljoufie, 2013b).

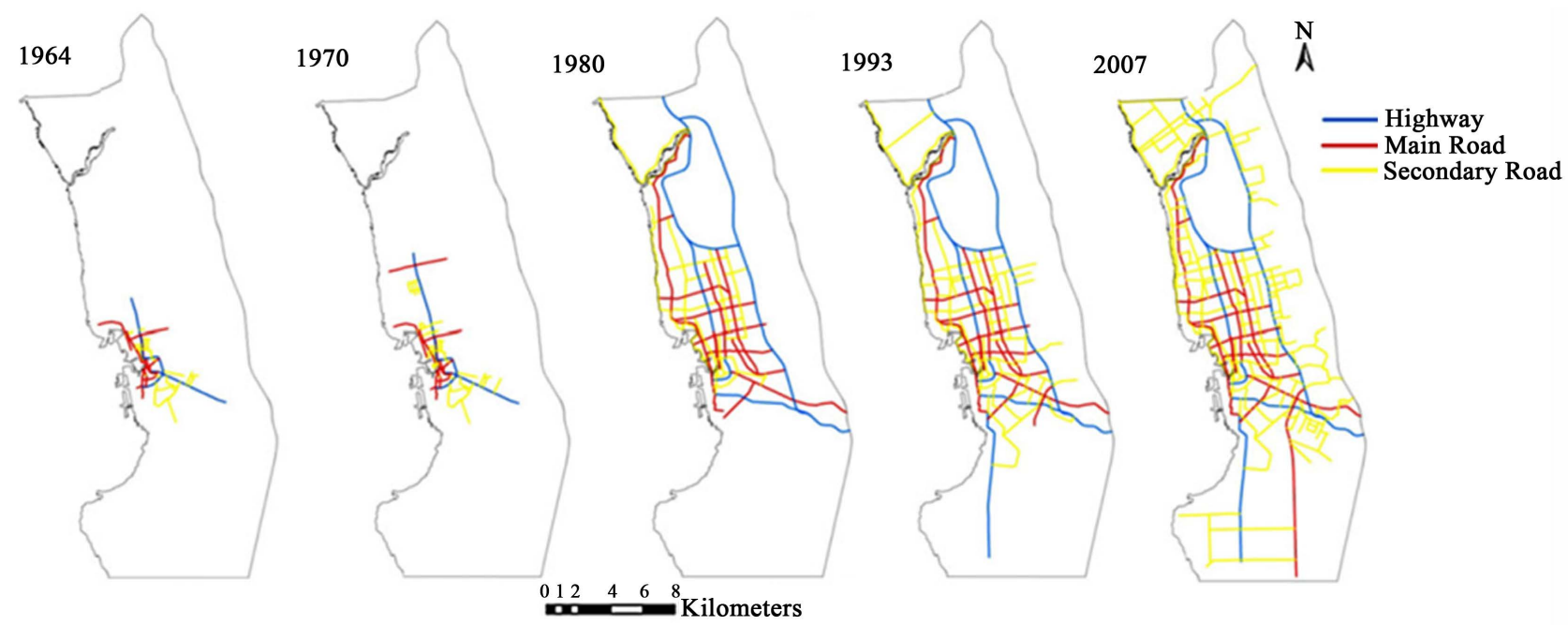

Figure 4. Evolution of the transport network in Jeddah city (Aljoufie, 2013b). 
Table 1. Evolution of population, urban area and road network in Jeddah between 1980 and 2015 (*: Aljoufie, 2013a and ${ }^{* *}$ : https://www.stats.gov.sa and estimates).

\begin{tabular}{cccccc}
\hline & $1980^{*}$ & $1993^{*}$ & $2002^{*}$ & $2007^{*}$ & $2015^{* *}$ \\
\hline $\begin{array}{c}\text { Spatial expansion } \\
\text { (hectares) }\end{array}$ & 32,500 & 40,739 & 49,700 & 54,175 & 58,600 \\
$\begin{array}{c}\text { Population growth } \\
\text { (persons) }\end{array}$ & 960,000 & $2,046,000$ & $2,560,000$ & $3,247,134$ & $3,457,794$ \\
$\begin{array}{c}\text { Residential land use } \\
\text { expansion (hectares) }\end{array}$ & 8724 & 14,921 & 19,318 & 21,365 & 23,200 \\
$\begin{array}{c}\text { Highways expansion } \\
\text { (kilometers) }\end{array}$ & 112 & 132 & 132 & 132 & 133 \\
$\begin{array}{c}\text { Main roads expansion } \\
\text { (kilometers) }\end{array}$ & 155 & 163 & 163 & 183 & 189 \\
$\begin{array}{c}\text { Secondary roads } \\
\text { expansion (kilometers) }\end{array}$ & 168 & 380 & 380 & 475 & 490 \\
\hline
\end{tabular}

\section{Data Description}

Data on education come from the Ministry of Education, the Regional Directorate for Education in Jeddah and the General Authority for Statistics (GAS). The population data by Mohafazat (governorates) come from the GAS, those per district come from the Municipality of Jeddah and previous scientific works (Daoudi, 2014; Al Sulami, 2010; Hamza et al., 2016). We also used the dasymetric population density map developed by Hamza et al. (2016). This map with that of the distribution of population extracted by the method per dot, is exploited to visualize the field of recruitment of each school and the need in secondary schools for each zone of habitation. These two maps are very effective in the present research, insofar as they give an idea on the distribution of the population very close to reality. Maps of urban sprawl, land use changes (Figure 3), and changes in the road network are also extracted from previous studies (Mandeli, 2008; Al Sulami, 2010; Baesse, 2012; Belarem et al., 2016, Al-Enazi, 2016a, 2016b; Aljoufie et al., 2013a, 2013b, 2013c, 2014a, 2014b, 2016a, 2016b; Chouari \& Belarem, 2017; Ajmi et al., 2014).

\section{Diagnosis of Girls' School Territories and Results}

The agglomeration of Jeddah comprises 2383 educational establishments. They are distributed as follow: 1225 state, 583 private and 575 international institutions. These establishments include: 327 maternal and elementary schools, 964 primary schools, 654 intermediate schools and 438 schools (Figure 5).

Girls' schools are in the order of 1312, including 194 secondary schools, 307 middle schools, 484 primary schools and 327 maternal schools (Figure 6(b)). Considering the legal status of institutions, $44 \%$ are public, $30 \%$ are private and $26 \%$ are transnational.

In the city of Jeddah, there are 301,468 female students, 1312 schools, 13,058 classes and 21,511 teachers; 230 girls per school, 23 girls per class, 14 girls for 


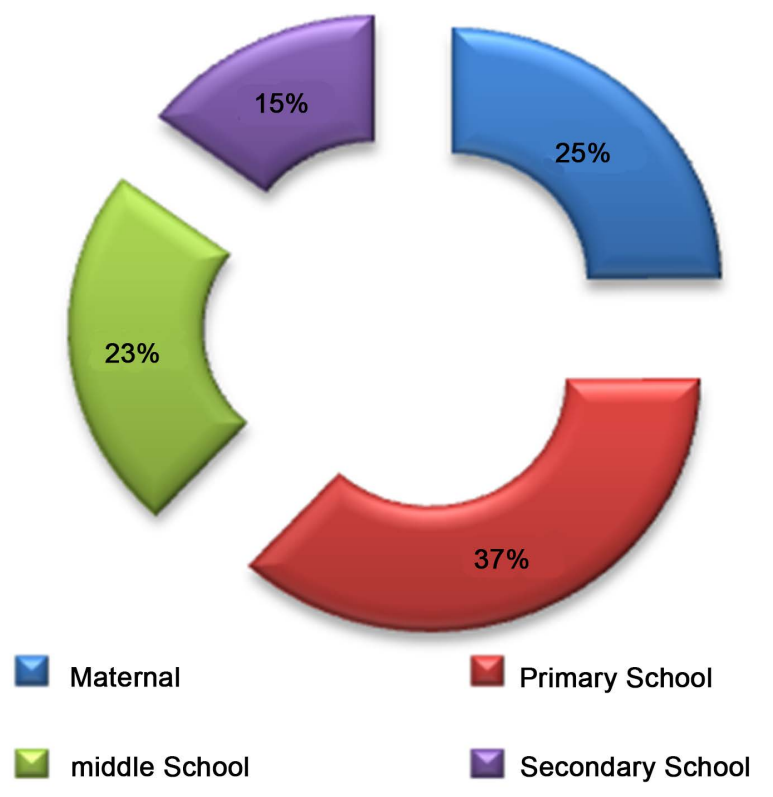

Figure 5. State education institutions in Jeddah by type (2015).
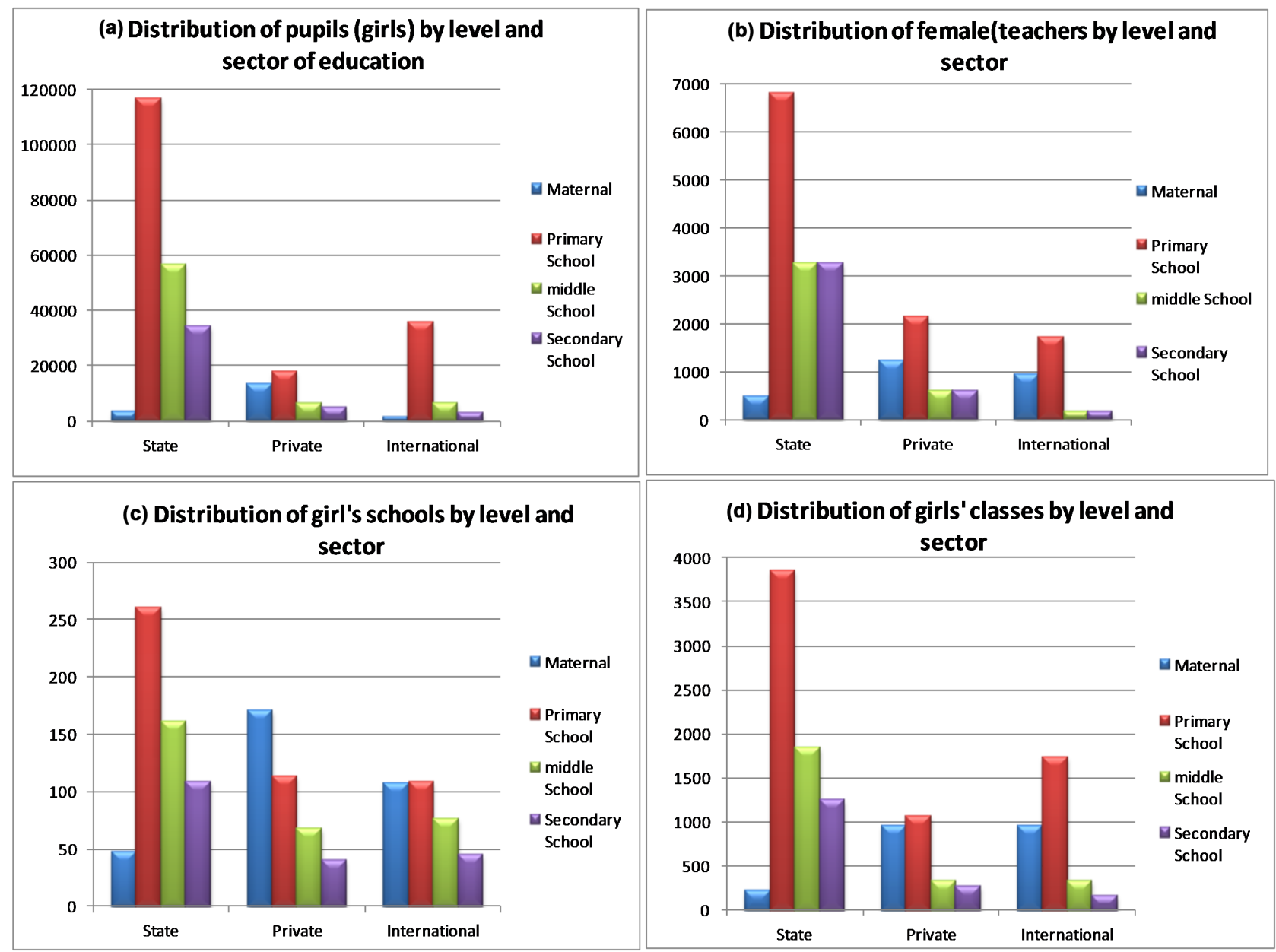

Figure 6. Teachers, classes and students (girls) in Jeddah (2015). 
each teacher. These values are relatively acceptable compared to other countries. In France, for example, the average number of students per secondary school is 563, with an average of 22 per class. In South Korea, this value is 29.1, in Turkey it is 26.5 (INSEE, 2008). However, the spatial distribution of settlements in Jeddah remains very uneven.

The secondary schools represent $18.38 \%$ of all the educational institutions of the city. The girl's secondary schools (public, private and transnational) are in the order of 194, those of the boy's count 244 . The girl's public secondary schools represent 56.18\% (109) of all the girl's secondary schools and almost $19 \%$ of the girl's schools. They recruit almost $81 \%$ of all girls $(34,294)$ enrolled in secondary education in the agglomeration (42,436 girls) (Figure 6(a)), 3277 female teachers (Figure 6(b)) and a few hundred of administrative agents. These secondary schools include 1264 teaching classes (Figure 6(c)).

\section{Spatial Distribution of Girls' Secondary Schools in Jeddah}

The spatial distribution of girls' secondary schools on the scale of the agglomeration of Jeddah shows a great imbalance between the districts. The following paragraphs deal with the unequal spatial distribution of these institutions in relation to the population pool. In addition to visualizing these spatial inequalities, we will propose alternatives to have a more rational school map.

An examination of the map of public girl's secondary schools (Figure 9) shows a great territorial inequality in the education sector. Indeed, there is a high concentration of secondary schools in the districts of the central part of the city. On the other hand, the districts of the south and the north of the city contain only a very limited number of secondary schools.

The present distribution, relatively proportional to the distribution of population numbers and densities (Figure 7 and Figure 8), shows that there is a large number of inhabitants who have accessing problems to the secondary schools.

The population map extracted by the method per point, the map of girls' secondary schools distribution and the one of the population density, show that most of the northern districts of the city (Al Zummurad, Al Yaqout, Teebah, and neighborhoods numbered 802, 803, 804, 805 and 806) and some of the southern ones (neighborhoods No. 501, 502, 503, 505, 506, 507, 508, and districts of No. 607 to No. 620), do not contain girls' secondary schools. The total population of these last districts is 121,347 inhabitants. They have a limited population compared to the districts of the central part. Their numbers of inhabitants vary between 124 in the district number 806 to 47,851 inhabitants in Al Marjan district. They are characterized by relatively low population densities (generally less than 7 inhabitants per $\mathrm{km}^{2}$ ). In this northern part there are also four districts which have a considerable population size: Al Basateen with 43,976 inhabitants $\mathrm{Al}$ Mohammadeyyah with 27,478, Al Naeem with 27478 and Al Nuzha with 27478 and do not have girls' secondary schools (Figure 9).

In the south part of the city, 22 neighborhoods (neighborhoods No. 501, No. 


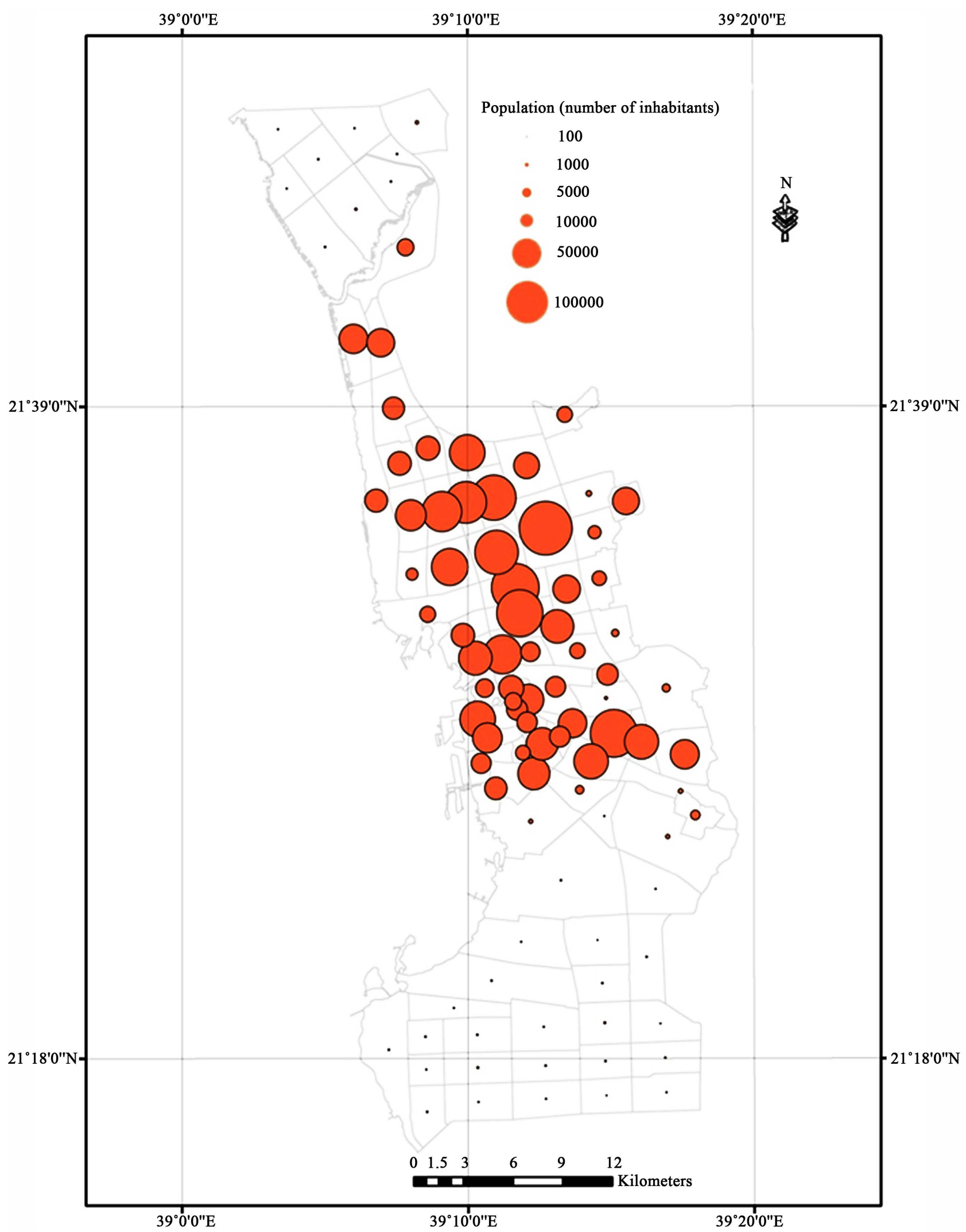

Figure 7. Population number by district in Jeddah City (Hamza et al., 2016). 


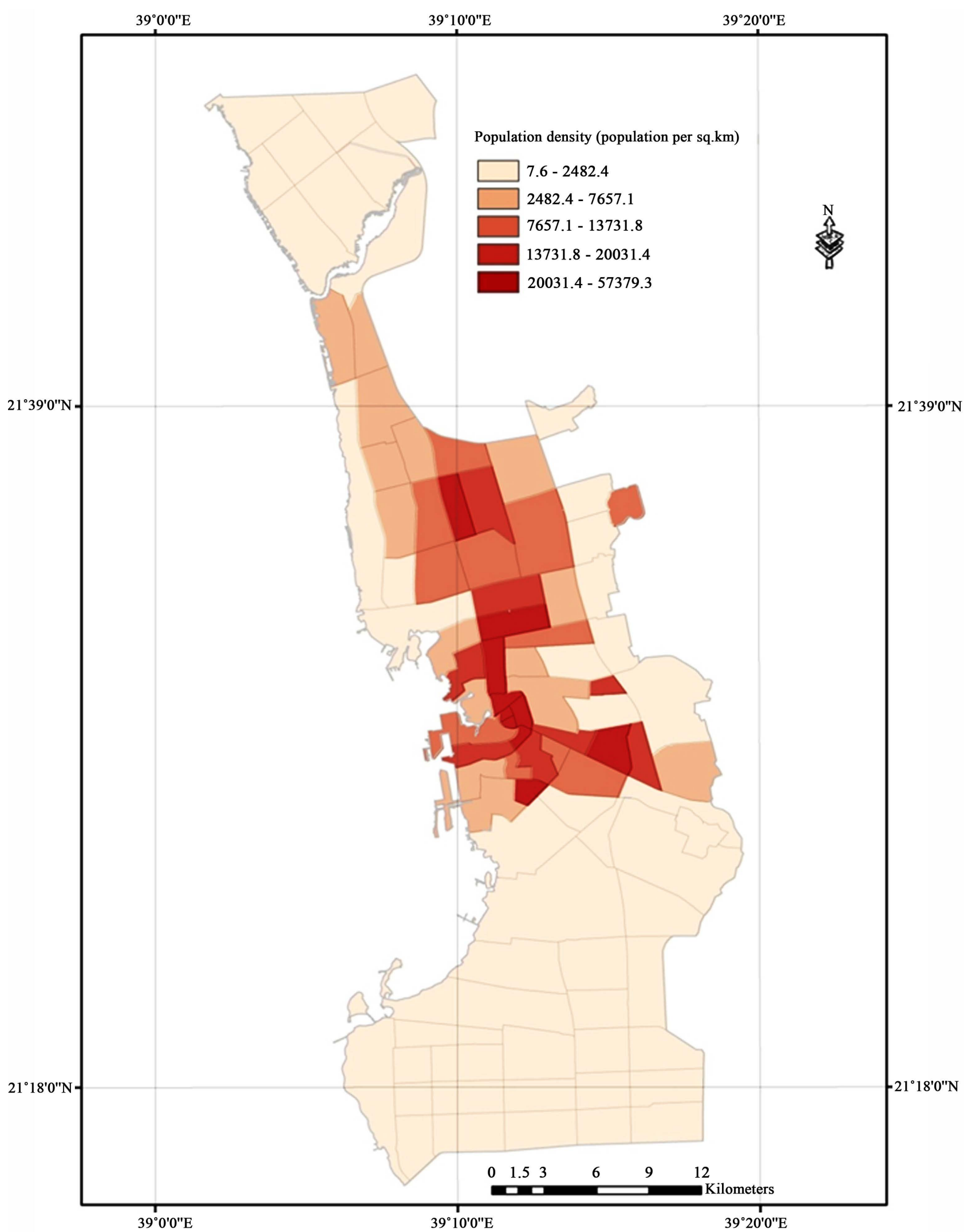

Figure 8. Choropleth map of Jeddah City (Natural breaks, Jenks classification) (Hamza et al., 2016). 


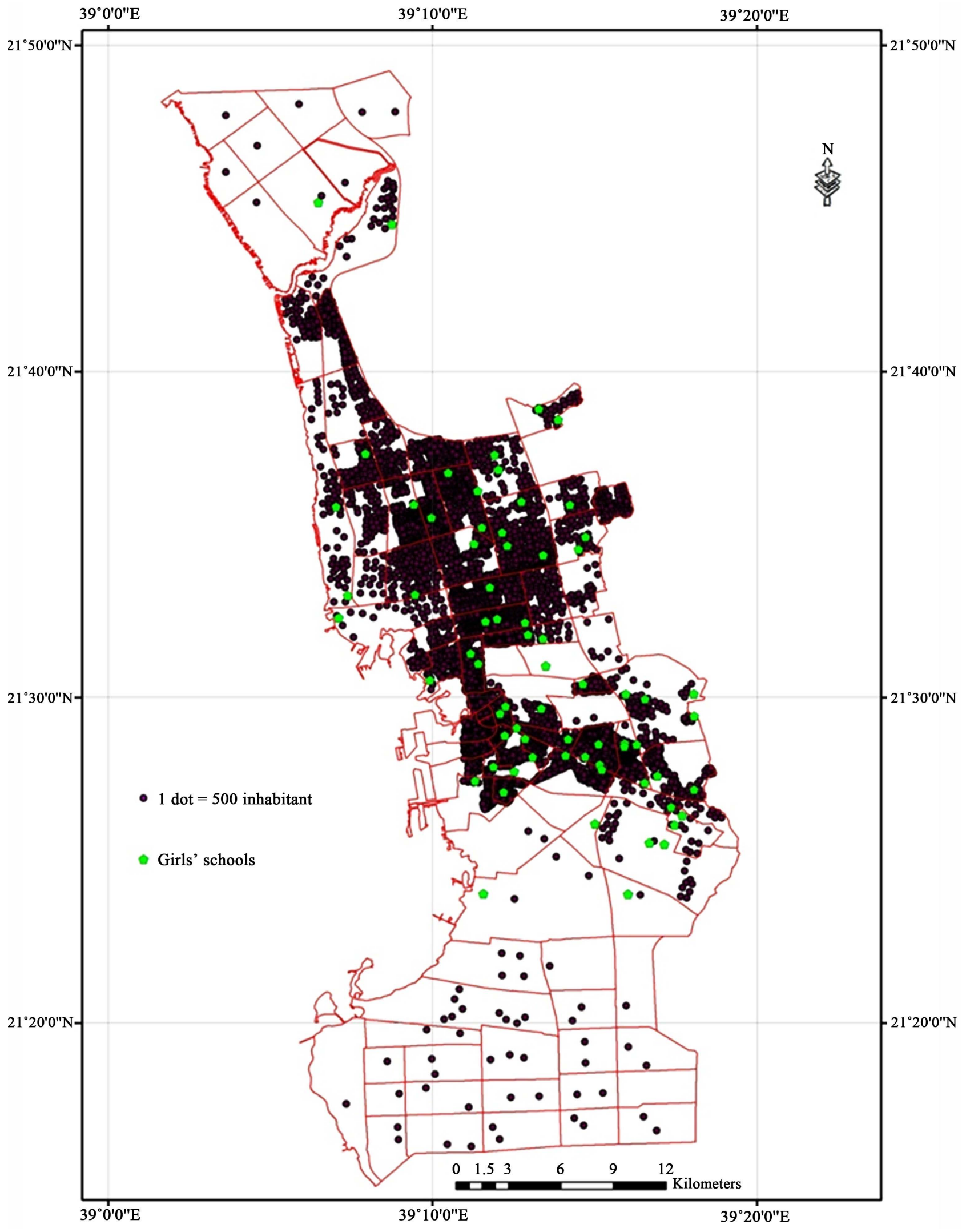

Figure 9. Girls' secondary schools and population number of Jeddah City (Method per dot). 
502, No. 503, No. 505, No. 506, No. 507, No. 508 and the neighborhoods No. 607 to No. 620) are the homes of 4149 inhabitants. Nevertheless, they do not have any girl's secondary school. Their populations vary between 118 and 278 inhabitants. As the northern neighborhoods, they are characterized by relatively low population densities (Figure 8).

On the other hand, the neighborhoods of the central part occupy the largest part of the population and have relatively high densities generally ranging from 100 to 600 inhabitants per $\mathrm{km}^{2}$ ) and have the majority of girls' secondary schools (Figure 7 and Figure 8).

The creation of buffer zones with different rays around girls' secondary schools (Figures 10-14) shows that a fairly large proportion of the population has problems with accessibility to these schools. The population with access problems varies with distance. Nearly $4.3 \%$ of the population live on shelves exceeding 5000 meters compared to girls' secondary school. These percentages increase respectively to $4.4 \%, 5.5 \%, 10.5 \%, 22 \%$ and $46 \%$ for distances of $4 \mathrm{~km}, 3$ $\mathrm{km}, 2 \mathrm{~km}, 1.5 \mathrm{~km}$ and $1 \mathrm{~km}$.

Accessibility to secondary schools becomes more difficult with the lack of a public transportation service for students. Indeed, with the exception of a few pickup services provided by private, and which remain very limited, all student travel is by car. In this way, there are as many displacements as pupils, teachers, workers, officials and administrative agents in these establishments (Aljoufie, 2016a, 2016b).

The situation has been aggravated by the weakness of public transportation service. The part of daily commuting by car in Jeddah has increased considerably, from 50\% in 1970 to $96 \%$ in 2012 (Aljoufie, 2014b). Public transport, walking and cycling account for only $4 \%$ of urban trips (Aljoufie, 2014b). There are two public transport networks by bus in Jeddah: the first is the Saudi Public Transport Company (SAPTCO), which operates as a regulated bus system. The second is COASTER Company, which is an unregulated bus service operated by private individuals. The SAPTCO system has 90 buses and operates on eight lines covering a total distance of $150 \mathrm{~km}$ (Aljoufie, 2014b) (Figure 15(a)). The second is composed by 10 bus lines with a distance of about $160 \mathrm{~km}$ (Figure 15(b)). COASTER has 1737 old buses with an average capacity of 20 passengers, only $5 \%$ of these vehicles are functional (Aljoufie, 2014b).

In the South zone, 22 neighborhoods lack girls' secondary schools (Figure 9 and Figure 10). The girls are therefore forced to travel long distances to reach the nearest schools. In the northern part, the same problem arises, indeed in seven districts there is no girls' secondary school. The southern zone which is the oldest part, is more spatially extended and has a larger population than the northern one. It has experienced a strong urban extension in recent years (Figure 9 and Figure 10). The northern zone is very recent but it knows a very accelerated rate of urbanization compared to that of the South. This situation requires the creation of at least one secondary school for each two adjacent 


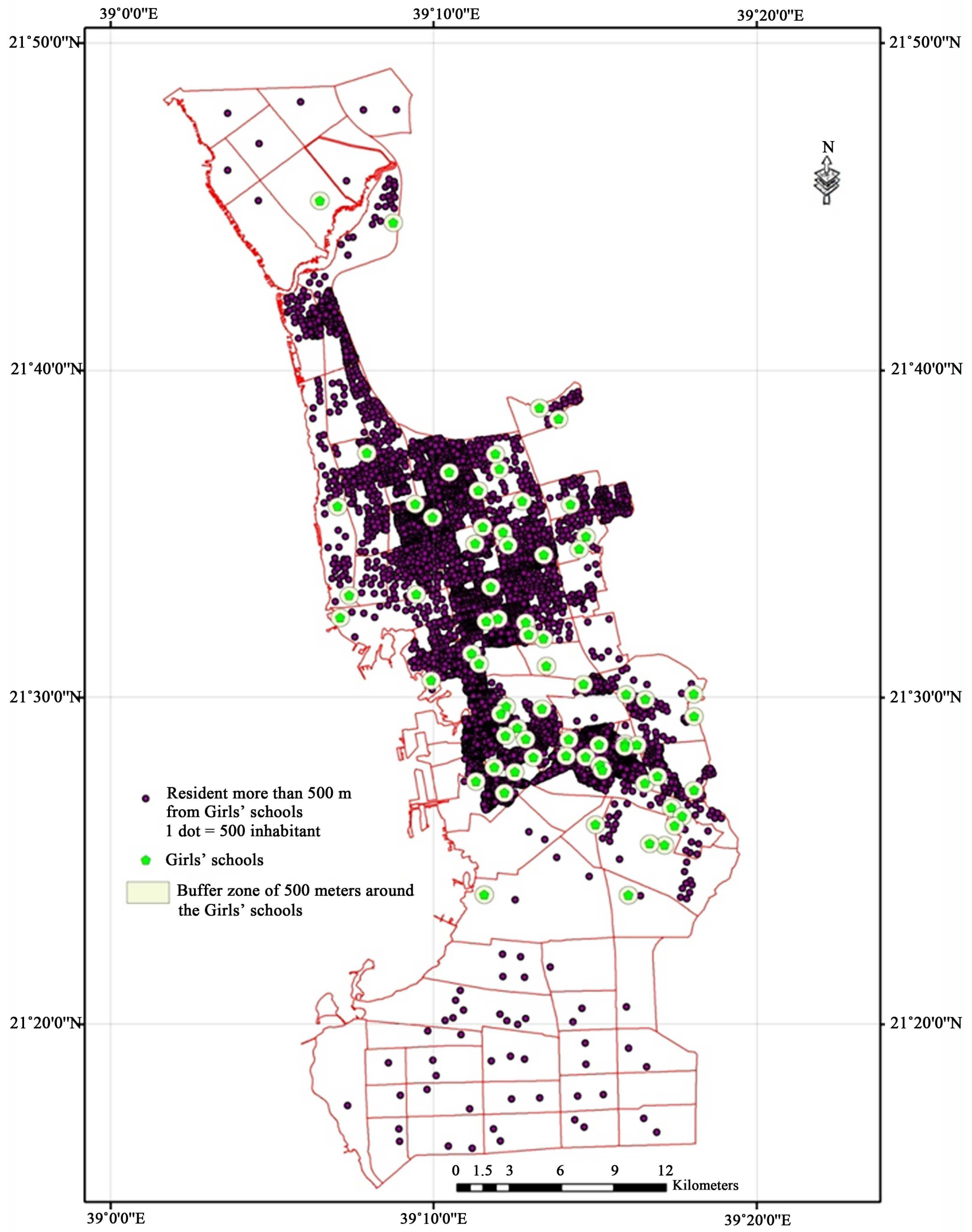

Figure 10. Population located more than 500 meters from a girls' secondary school in 2015. 


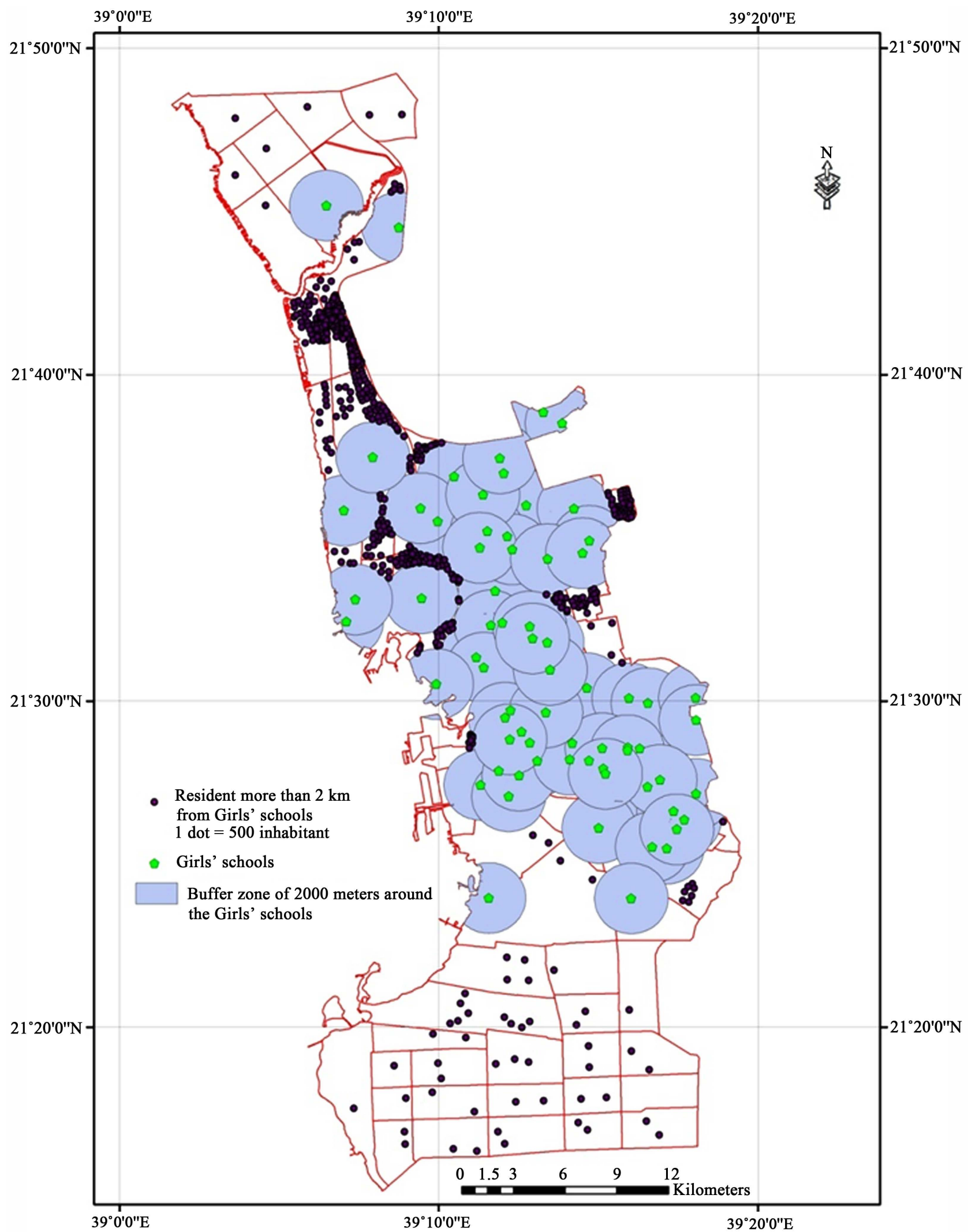

Figure 11. Population located more than 2 kilometers from a girls' secondary school in 2015. 


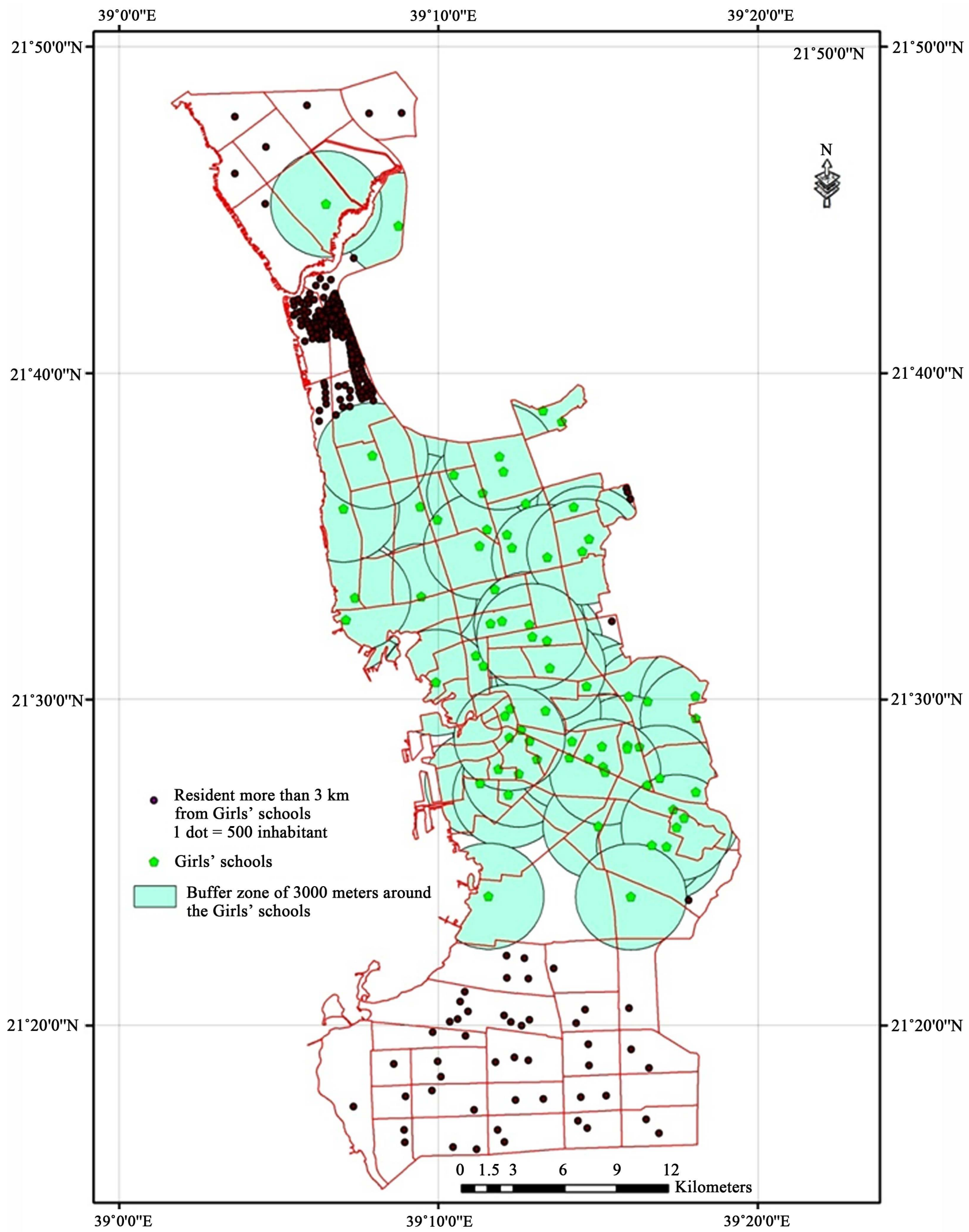

Figure 12. Population located more than 3 kilometers from a girls' secondary school in 2015. 


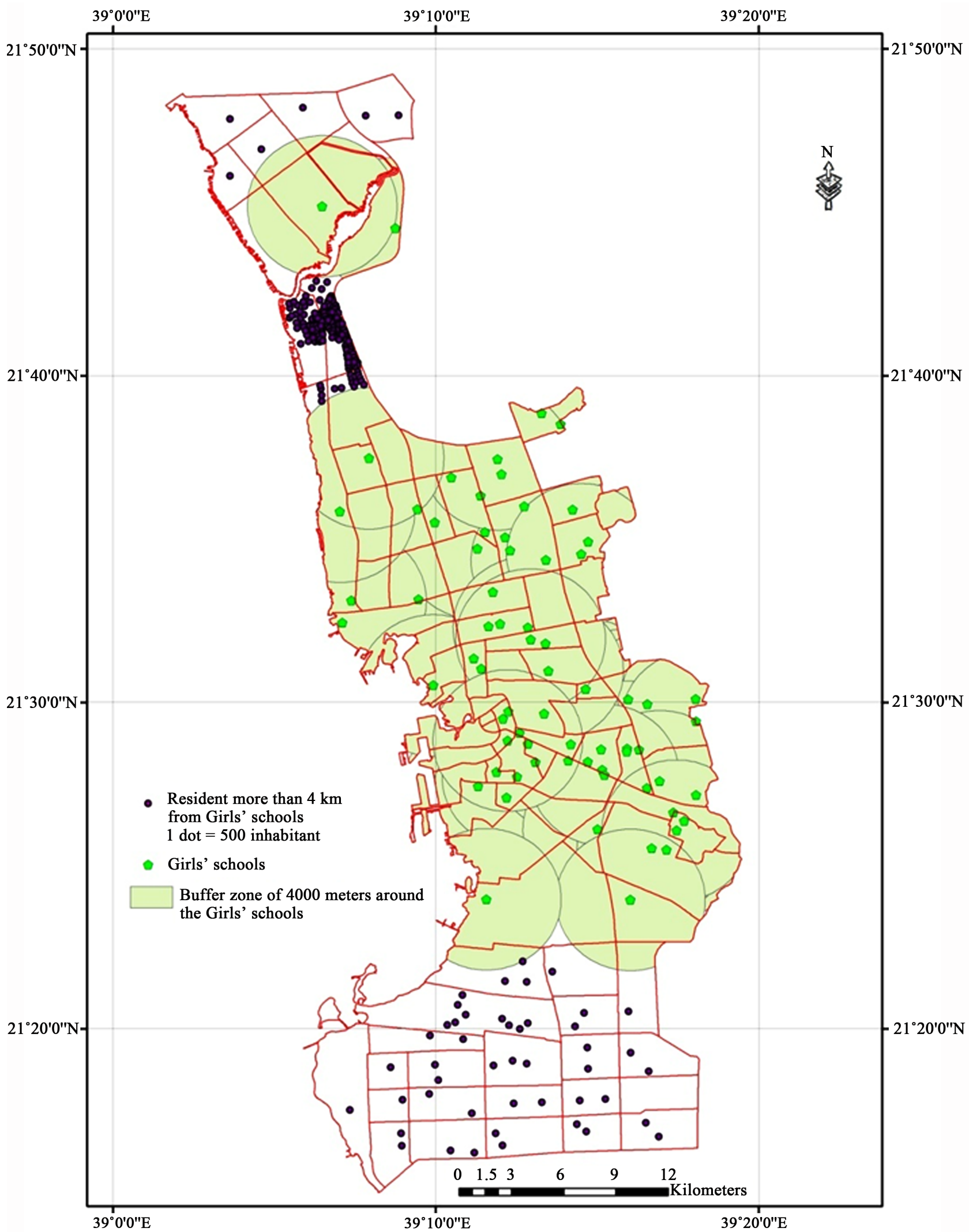

Figure 13. Population located more than 4 kilometers from a girls' secondary school in 2015. 


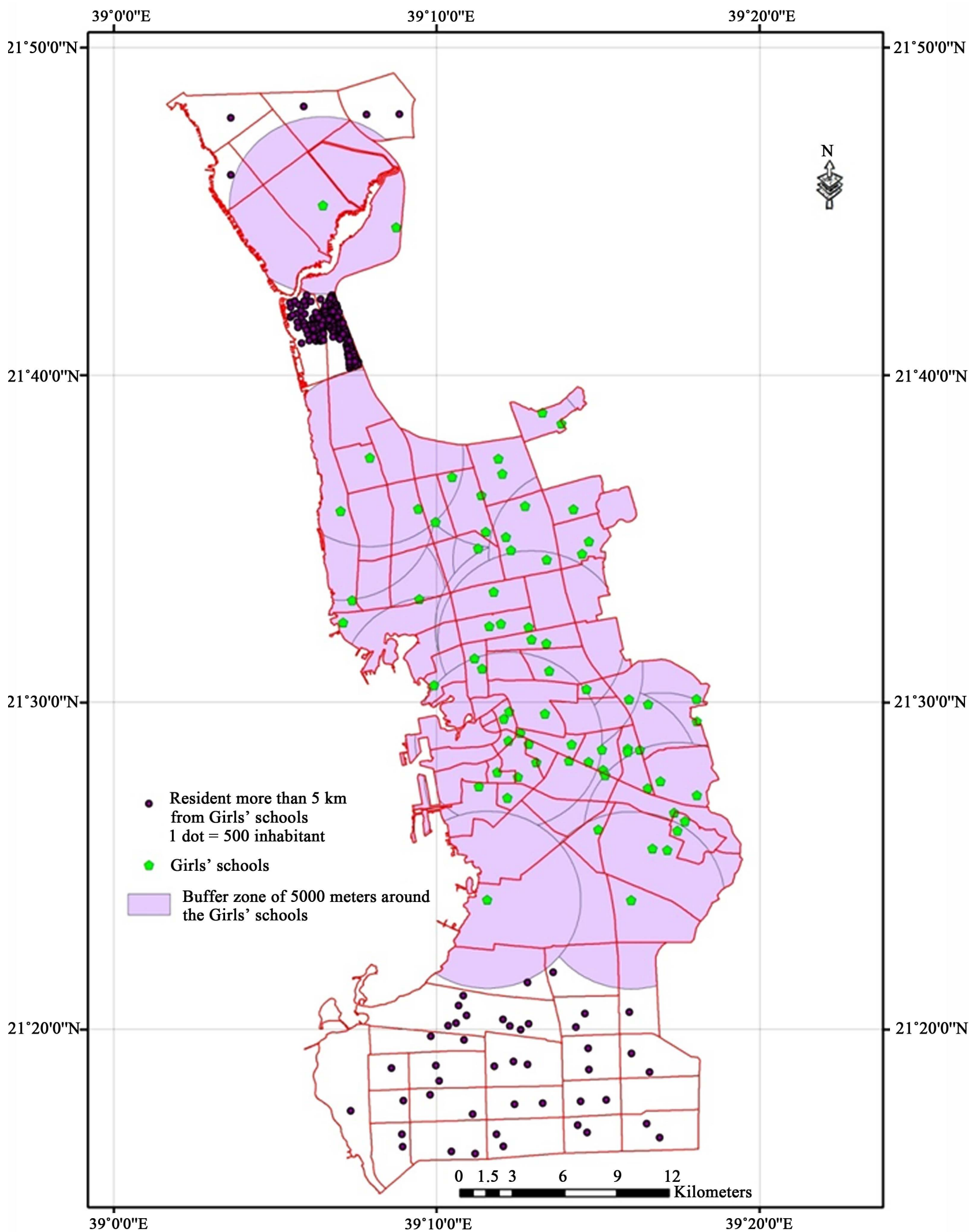

Figure 14. Population located more than 5 kilometers from a girls' secondary school in 2015. 


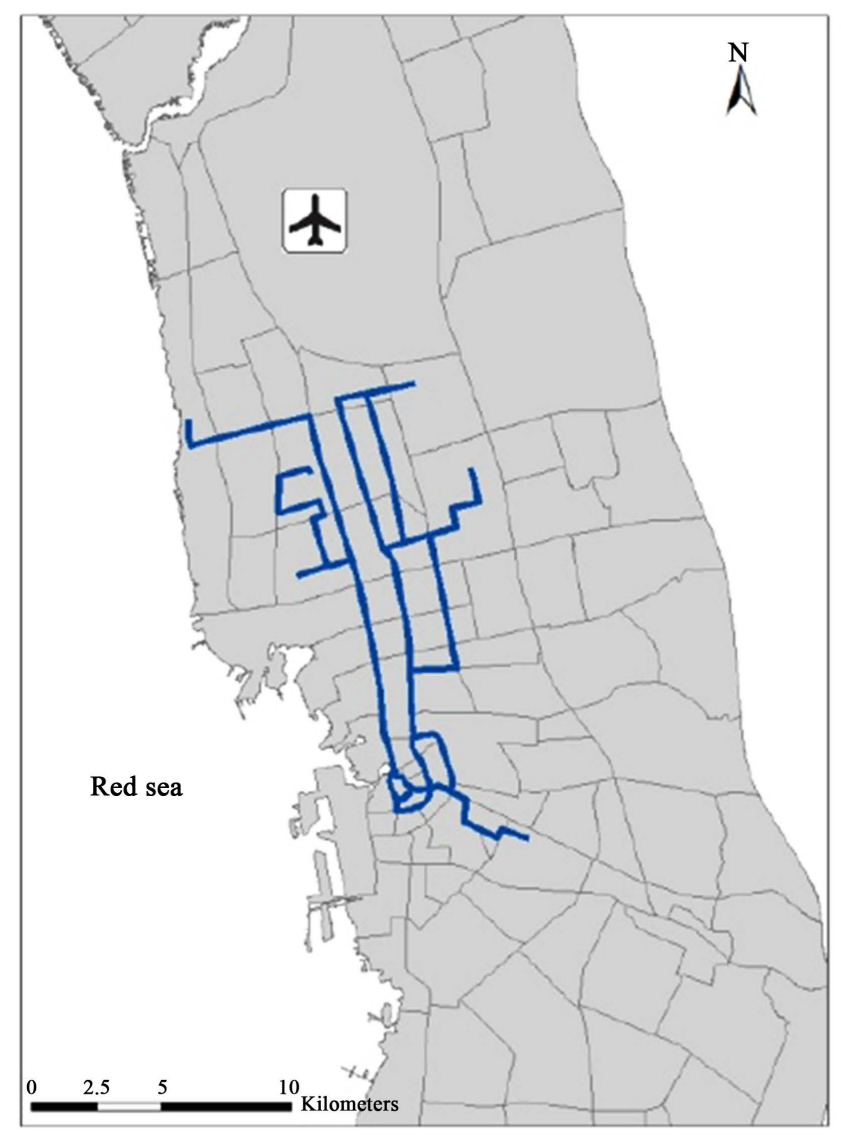

(a)

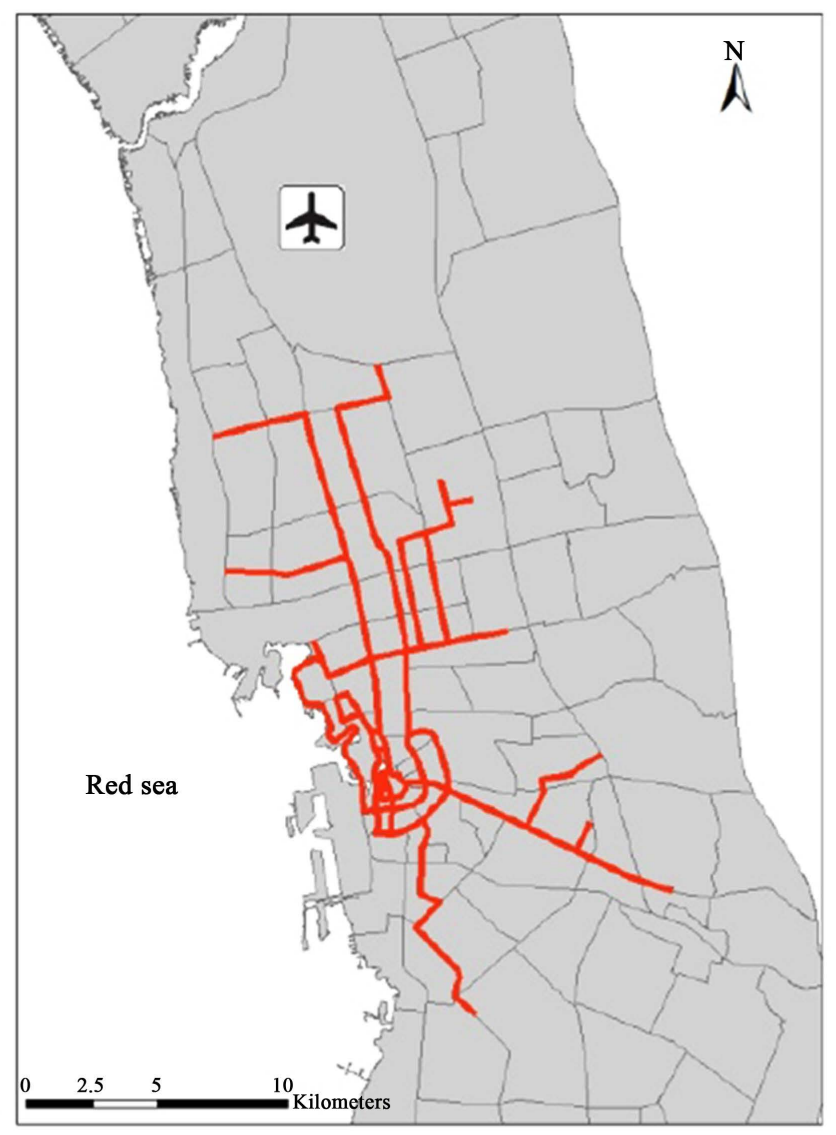

(b)

Figure 15. Jeddah public transport lines (Aljoufie, 2014b). (a) SAPTCO service lines; (b) Unregulated coaster buses service lines.

districts; therefore it is necessary to develop at least 10 secondary schools in the South and 3 secondary schools in the North, with the improvement of the collection service for girls by school buses.

It appears that although the distribution of girls' secondary schools is proportional to that of population numbers and densities, the inhabitants of the North and South of the city have great problems of access to secondary schools compared to the inhabitants of the central area.

\section{Conclusion and Recommendation}

In the present study, the situation is characterized by an imbalance in the distribution of urban girl's secondary schools, of population numbers and densities and of facilities; by an urban expansion and increasingly accelerated networks; by a lack of a Transport service for the pupils, the weakness of urban collective transport, means that the intervention of the state becomes very urgent.

The solution consists in the creation of a school bus service, the development of a public transport network (subway, tramway, private bus transportation...), the encouragement of low impact transportation (walking, cycling, etc.) and therefore the reduction of the share of cars in the urban displacements. The offi- 
cial authorities must also intervene on the map of schools through the creation of new girl's secondary schools especially in the south and in the north of the city.

\section{Acknowledgements}

This project was funded by the Deanship of Scientific Research (DSR) at King Abdulaziz University, Jeddah, Kingdom of Saudi Arabia, under grant No. G-1436-125-484. The authors, therefore, acknowledge with thanks DSR for technical and financial support.

Dr. Mongi BELAREM, Principle-Investigator.

Dr. Mohamed Hafedh HAMZA, Co-Investigator.

Dr. Abdelhamid JAMIL, Co-Investigator.

\section{References}

Ajmi, M., Hamza, M. H., Labiadh, M., Yermani, M., Ben Khatra, N., Al-Thubaiti, A. S., Moharrem, I. A., \& El Arrim, A. (2014). Setting up a Spatial Data Infrastructure (SDI) for the ROSELT/OSS Network. Journal of Geographic Information System, 6, 150-161. https://doi.org/10.4236/jgis.2014.62016

Al Sulami, M. (2010). La transformation socio-spatiale à Djeddah (Arabie saoudite) (563 p). Thèse de doctorat en géographie, Sorbonne: Université Paris IV.

Al-Enazi, M. (2016b). Traffic Congestion Evaluation Using GIS Case Study: Jeddah City. International Journal of Computer Applications (0975-8887), 138. http://www.ijcaonline.org/research/volume138/number1/alenazi-2016-ijca-908634.pdf

Al-Enazi, M., Mesbah, S., \& Anwar, A. (2016a). Schools Distribution Planning Using GIS in Jeddah City. International Journal of Computer Applications (0975-8887), 138. http://www.ijcaonline.org/research/volume138/number1/alenazi-2016-ijca-908693.pdf

Aljoufie, M. (2014a). Toward Integrated Land Use and Transport Planning in Fast-Growing Cities: The Case of Jeddah, Saudi Arabia. Habitat International, 41, 205-215. http://www.sciencedirect.com/science/article/pii/S0197397513000945 https://doi.org/10.1016/j.habitatint.2013.08.010

Aljoufie, M. (2014b). Spatial Analysis of the Potential Demand for Public Transport in the City of Jeddah, Saudi Arabia. In C. A. Brebbia (Ed.), Urban Transport $X X$ (pp. 113-123). Southampton: WIT Press.

http://www.witpress.com/Secure/elibrary/papers/UT14/UT14010FU1.pdf https://doi.org/10.1016/j.sbspro.2015.12.013

Aljoufie, M. (2016a). Analysis of Illegal Parking Behavior in Jeddah. Current Urban Studies, 4, 393-408. http://file.scirp.org/pdf/CUS_2016101914445091.pdf

Aljoufie, M. (2016b). Exploring the Determinants of Public Transport System Planning in Car-Dependent Cities. Procedia-Social and Behavioral Sciences, 216, 535-544. http://www.sciencedirect.com/science/article/pii/S1877042815061935 https://doi.org/10.1016/j.sbspro.2015.12.013

Aljoufie, M., Brussel, M., Zuidgeest, M., \& Maarseveen, M. V. (2013a). Urban Growth and Transport Infrastructure Interaction in Jeddah between 1980 and 2007. International Journal of Applied Earth Observation and Geoinformation, 21, 493-505.

http://www.sciencedirect.com/science/article/pii/S0303243412001444

https://doi.org/10.1016/j.jag.2012.07.006 
Aljoufie, M., Zuidgeest, M., Brussel, M., \& Maarseveen, M. V. (2013b). Spatial-Temporal Analysis of Urban Growth and Transportation in Jeddah City, Saudi Arabia. Cities, 31, 57-68. http://www.sciencedirect.com/science/article/pii/S0264275112000789 https://doi.org/10.1016/j.cities.2012.04.008

Aljoufie, M., Zuidgeest, M., Brussel, M., Vliet, J., \& Maarseveen, M. V. (2013c). A Cellular Automata-Based Land Use and Transport Interaction Model Applied to Jeddah, Saudi Arabia. Landscape and Urban Planning, 112, 89-99.

http://www.sciencedirect.com/science/article/pii/S0169204613000042

https://doi.org/10.1016/j.landurbplan.2013.01.003

Baesse, S. S. O. (2012). Towards More Effective Urban Planning in Jeddah, Saudi Arabia (304 p.). Doctoral Thesis of Philosophy in Urbain Planning, Melbourne: RMIT University, Melbourne School of Global Studies, Social Science and Planning. https://researchbank.rmit.edu.au/eserv/rmit:161451/Baesse.pdf

Belarem, M., Benasr, A., Grasland, C., \& Chouari, W. (2016). Le monde vu par les étudiants de Sfax in revue Mappemonde $n 116$. http://mappemonde-archive.mgm.fr/num45/articles/art15101.html

Caro, P., Faivre, E., \& Grosjean, F. (2006a). La carte outil de diagnostic et de perspective pour les politiques scolaires. Revue Mappemonde, 82, 1-7.

http://mappemonde.mgm.fr/num10/articles/art06202.html

Caro, P., Faivre, E., \& Grosjean, F. (2006b). La territorialisation des politiques. Annales de Géographie, 115, 434-448.

http://www.persee.fr/doc/geo_0003-4010_2006_num_115_650_21449

https://doi.org/10.3406/geo.2006.21449

Chouari, W., \& Belarem, M. (2017). Enjeux de la Tunisie orientale: Un territoire développé et un environnement à protéger.

http://journals.openedition.org/confins/11701

Daoudi, M. (2014). Risque d'inondation et vulnérabilité de la ville de Djeddah, Arabie saoudite. Geo-Eco-Trop, 38, 259-270.

http://www.geoecotrop.be/uploads/publications/pub_382_03.pdf

Ewea, H. A. (2010). Hydrological Analysis of Flooding Wastewater Lake in Jeddah, Saudi Arabia. Journal of King Abdulaziz University: Meteorology, Environment and Arid Land Agriculture Sciences, 21, 125-144. https://doi.org/10.4197/met http://www.kau.edu.sa/Files/320/Researches/57109_27378.pdf

Hamza, M. H., Al-Thubaiti, A. S., Dhieb, M., Bel Haj Ali, A., Garbouj, M. S., \& Ajmi, M. (2016). Dasymetric Mapping as a Tool to Assess the Spatial Distribution of Population in Jeddah City (Kingdom of Saudi Arabia). Current Urban Studies, 4, 329-342. https://doi.org/10.4236/cus.2016.43022

INSEE (2008). https://www.insee.fr/fr/accueil

Mandeli, K. N. (2008). The Realities of Integrating Physical Planning and Local Management into Urban Development: A Case Study of Jeddah, Saudi Arabia. Habitat International, 32, 512-533.

http://www.sciencedirect.com/science/article/pii/S0197397508000088 